\title{
DINAMIKA PERAN PEREMPUAN : SEBUAH KAJIAN PERAN PEREMPUAN DALAM PERSPEKTIF ISLAM DAN PSIKOLOGI
}

\author{
Ima Sri Rahmani \\ Fakultas Psikologi Univesitas Islam Negeri (UIN) Syarif Hidayatullah Jakarta \\ E-mail: imasrirahmani@uinjkt.ac.id
}

\begin{abstract}
Abstrak: Tulisan ini mencoba menelisik berbagai peran dan tanggung jawab yang harus dijalani seorang perempuan : sebagai ibu rumah tangga dan sebagai pekerja. Dua peran yang memiliki pola kerja dan bentuk tanggung jawab yang sangat berbeda. Karena perbedaan ini, tak jarang menimbulkan konflik yang berpengaruh pada produktifitas dan kinerja baik sebagai pekerja maupun sebagai ibu rumah tangga. Kondisi ini tentu sangat berpengaruh terhadap kesejateraan subjektif perempuan itu sendiri. Sebagai pisau analisis penulis menggunakan kajian perspektif islam dan psikologi guna memahami dinamika yang terjadi dan untuk mendapatkan jalan keluar yang tepat.
\end{abstract}

Kata Kunci: islam, psikologi, peran, kesejahteraan subjektif, perempuan

\section{PENDAHULUAN}

Sudah lebih dari dua minggu, Andi, sebut saja begitu, tidak masuk sekolah. Tak ada alasan yang pasti, hanya tidak ingin pergi ke sekolah dan ingin diam di rumah saja. Kedua orang tuanya tampak sangat gusar. Dalam sesi konseling, ayahnya bercerita tentang segala upaya yang sudah dilakukan untuk membujuk anaknya kembali ke sekolah. Hingga jalan pintas akibat tersulut emosi berupa tindakan kekerasanpun akhirnya dilakukan. Ibunya, yang tak kalah cemasnya tampak begitu bingung. Kebingungan yang teramat kuat. Bukan hanya bingung bagaimana harus menghadapi perilaku anaknya. Tapi juga kebingungan bagaimana harus membagi waktu antara pengasuhan anak anaknya dan pekerjaannya, "Saya bekerja. Beruntung jika saya mendapat jadwal piket kerja di sore hari. Sehingga di pagi hingga siang hari saya dapat mengatur segala kebutuhan anak anak sebelum berangkat ke sekolah. Namun jika saya harus melaksanakan piket di pagi hari. Saya harus berangkat bekerja pagi sekali agar dapat tiba di tempat kerja tepat waktu. Apalagi kemacetan di Jakarta sulit diprediksi”. Ketika ditanyakan perihal pengawasan dan pengasuhan anak selama bekerja, ibu yang berprofesi sebagai perawat ini menjelaskan dengan lirih, "Sejak anak pertama hingga anak yang ke tiga, kami titipkan mereka pada tetangga yang sudah kami percaya”.

Fenomena tersebut pada kenyataannya terjadi pada banyak pasangan muda. Alternatif lain yang dapat dilakukan adalah dengan menitipkan anak pada asisten rumah tangga. Beruntung mereka yang masih memiliki nenek atau kakek yang bersedia memberikan perhatian dan pengawasan pada cucunya. Seperti pengakuan sepasang nenek dan kakek yang rutin dan rajin mengikuti sesi pertemuan orang tua wali murid, "Sejak bayi, dia kami yang asuh. Kedua orang tuanya harus bekerja. Sebenarnya mereka bekerja di luar kota, jauh dari tempat tinggal kami. Daripada cucu saya diasuh oleh pembantu, maka saya memutuskan untuk membawa cucu saya tinggal di rumah saya. Satu bulan sekali ibu bapaknya akan datang berkunjung untuk menengok anaknya”. 


\section{9-115 | HARKAT: Media Komunikasi Islam Tentang Gender dan Anak, 11(2), 2015}

Terlepas dari perdebatan alternatif mana yang paling baik, kondisi dilematis seperti ini tampak seperti persoalan klasik yang seakan wajar terjadi dan dialami pasangan muda. Pertanyaan yang kerapkali muncul kepada para ibu dan menjadi tantangan besar para perempuan adalah, "Pilih mana, pekerjaan atau anak ?"

\section{PEMBAHASAN}

\section{Simbol dan Peran: Kepanikan Gender...?}

Pada kenyataannya simbol pengasuhan lekat pada perempuan dibanding laki - laki. Dalam kancah sosial, manusia berbagi simbol komunikasi ketika berinteraksi. Berdasar pada prinsip kerangka kerja symbolic interactionsm persoalan akan muncul jika simbol - simbol yang dipergunakan dalam kontak sosial tidak bekerja sesuai dengan fungsi sosialnya. Simbol pengasuhan yang melekatkan fungsi sosial peran seorang ibu yang dipahami masyarakat ini menjadi bagian dari penilaian untuk menentukan pilihan mana yang paling tepat. Tepat sesuai dengan fungsi sosialnya yaitu berperan sebagai pengasuh bagi anak - anaknya. Status yang berhubungan dengan jenis kelamin oleh Granfinkel seperti yang dikutip oleh Brouwer (1989) disebut sebagai factum natural, yang merupakan suatu factum morale.

Untuk memahaminya kita dapat menelisik dengan mencoba memahami esensi peran yang muncul sebagai bagian dari fungsi sosial. Setidaknya terdapat tiga makna peran yang ditetapkan berdasarkan kontek sosialnya yaitu peran dalam kontek prescrit (petunjuk), peran dalam kontek subjectif (individu) dan peran dalam kontek mis en act (tindakan) (Bouchet, Chanton, Kreel, Maze, Ric, \& Richard, 1992).

Dalam kontek prescript (petunjuk), peran muncul bersama dengan perilaku yang terjadi dalam konteks sosial dan berbagai posisi yang dimiliki oleh subjek. Dalam konteks ini, peran ibu dengan persoalan yang dialami oleh anaknya di sekolah di satu sisi dan perannya sebagai perawat di sisi lain, merupakan dua hal yang menjadi bahan penilaian dan pertimbangan untuk dimunculkan dalam konteks sosial. Identitas mana yang sebaiknya dimunculkan sebagai petunjuk dalam interaksi sosial? Konflik muncul ketika dua petunjuk peran dimainkan dalam satu waktu untuk menyelesaikan satu persoalan tertentu. "Sebagai sorang ibu saya bertanggung jawab sepenuhnya akan keselamatan dan masa depan anak saya, seperti halnya saya bertanggung jawab sepenuhnya akan segala tugas yang sudah diembankan kepada saya sebagai seoarang perawat", adalah satu contoh ketika komunikasi dibangun untuk menentukan jalan keluar terbaik bagi anak yang tengah mengalami persoalan di sekolah. Akan terasa sulit bagi pihak sekolah dalam menyikapi kondisi seperti ini.

Sedangkan dalam kontek subjectif (individu) peran muncul bersama harapan yang di miliki oleh subjek vis - a - vis dengan harapan orang lain dalam interaksi dengan subjek lain dan di dalam posisi diri yang berbeda. Dalam kontek ini, penilaian subjektif untuk masing masing peran lebih menonjol. Karakter pribadi individu menjadi faktor yang paling menentukan ketegasan sikap, "Mengikuti penilaian pribadi atau mengikuti penilaian orang lain?". Konflik muncul ketika sistem nilai subjektif individu berseberangan dengan sistem nilai subjektif orang lain, terutama orang yang signifikan bagi subjek itu sendiri.

"Saya ingin sekali dapat tetap bekerja agar dapat memiliki penghasilan sendiri, namun tampaknya suami saya menghendaki saya tetap di rumah merawat dan membesarkan anak - anak selama suami saya bekerja”.

Dan dalam kontek mis en act (tindakan) peran bersama dalam tindakan perilaku yang efektif yang dilakukan subjek dalam interaksi dengan orang lain. Dalam kontek ini, individu dituntut untuk proporsional dan konsisten dengan peran yang sedang dijalani dalam bentuk 
tindakan. Tak jarang seorang individu harus secara total menanggalkan peran- perannya yang lain yang dipandang bertentangan dengan peran yang sedang ditampilkan. Sebagai contoh, jika penilaian subjektif tentang peran seorang ibu adalah murni mengurus kepentingan rumah tangga maka perilaku yang muncul adalah sebaik mungkin mencirikan peran sebagai ibu rumah tangga tanpa mempertimbangkan lagi tanggung jawab yang harus dilakukan serta keuntungan atau kerugian yang mungkin didapatkan ketika perannya sebagai seorang perawat harus ditinggalkan. Konflik terjadi ketika keputusan yang diambil tidak sepenuh hati. "Saya akhirnya memilih untuk berhenti bekerja, meskipun sebenarnya saya ingin bekerja. Bekerja tetap merupakan passion bagi saya. Saya menjadi kurang bersemangat menyelesaikan tugas - tugas rumah tangga, apalagi mencuci pakaian dan memasak. Saya tetap menjalin komunikasi dan sering membuat janji bertemu dengan kawan kawan kerja saya dahulu”.

Konflik yang menyertai bentuk berbagai peran di atas dapat menimbulkan persoalan psikologis. Tidak hanya karena tekanan pribadi untuk menetukan peran yang tepat sesuai dengan konteknya, namun juga karena banyaknya status yang dimiliki yang memungkinkan seseorang menjadi tidak begitu menguasai peran yang diembannya (incompetence). Sebagai akibat dari ketidak sesuaian antara satu peran dengan peran yang lain yang mungkin malah saling bertolak belakang.

Kelelahan yang diakibatkan oleh peran ganda akibat konflik - perbenturan di antara keinginan untuk terus bergantung pada rasa aman dalam rumah yang selama ini dinikmati wanita yang terikat pada rumahnya, dengan keinginan untuk bebas dan mewujudkan diri menurut Dowling (1989) dapat menimbulkan kepanikan gender jika tidak teratasi yang pada akhirnya akan mengikat wanita pada pekerjaan pekerjaan bertaraf rendah atau yang tidak sesuai bagi mereka, serta membuat mereka tetap bekerja terlalu keras di rumah.

\section{Kepribadian dan Efektifitas Kerja pada Perempuan Multiperan Perempuan}

Akhirnya, berdasar pada berbagai status yang diemban oleh seseorang, hukum dan kewajiban lah yang dapat membatasi status peran relasi seorang perempuan ketika berhadapan dengan status peran orang lain dalam kancah sosial (Hogg \& Vaughan, 2010). Meminjam istilah Garfinkel (dalam Brouwer, 1989) hukum dan kewajiban dalam suatu peran menjadi the rules of interpretation defining our position in the group. Kuat atau lemahnya konflik yang dialami tergantung pada tingkat ketegangan tuntutan antar peran dan pada ketidak sesuaian antar tuntutan (berdasar pada hukum dan kewajiban) peran yang terjadi. Bayangkan dalam kondisi di mana si ibu terpaksa harus membawa bayinya ke tempat kerja karena tidak adanya asisten rumah tangga. Pada akhirnya hukum dan kewajiban yang mendorong si ibu untuk tetap bekerja walaupun harus dengan bayi di sampingnya. Bagaimana si ibu mengatasi hal ini?

Dalam berbagai kontek peran yang diemban seorang perempuan, kepribadian menjadi bagian yang esensial dalam menentukan bagaimana peran yang beragam dalam beragai konteks tersebut dapat muncul di permukaan. Seperti yang diungkapkan oleh Alport (dalam Mischel, Yuichi, \& Ayduk, 2007) bahwa kepribadian merupakan suatu organisasi system psychophysical yang dinamis di dalam diri individu yang menentukan karakter perilaku dan berfikir individu tersebut. Kepribadian merupakan faktor penentu yang mempengaruhi seseorang dalam berhubungan dengan dunia sosial. Oleh sebab itu Brouwer (1989) mendefinisikan kepribadian sebagai corak tingkah laku sosial yang terkadang kelihatan (overt) dan terkadang tidak kelihatan (covert). Karena kepribadian diorganisasikan maka ketika terjadi perpecahan atau ketidak selarasan/ketidak 


\section{1 -115 | HARKAT: Media Komunikasi Islam Tentang Gender dan Anak, 11(2), 2015}

teraturan maka akan terjadi gangguan (Mischel et.al., 2007).

Jelas kiranya hubungan antar peran dan kepribadian bersifat kompleks dan bervariasi tergantung situasi. Setidaknya kepribadian dapat mempengaruhi efektifitas peran perempuan ketika peran yang harus ditampilkan sesuai dengan tipe kepribadian yang dimiliki. Yaitu ketika suatu kepribadian menjadi bagian dari suatu peran tertentu dan ketika suatu peran tertentu dibutuhkan sebagai alat yang dapat mendukung kepribadian yang harus ditampilkan. Konflik muncul diakibatkan oleh kepribadian ketika predisposisi kepribadian tidak cocok dengan tuntutan peran atau ketika peran yang disandingkan pada seseorang tidak sesuai dengan kepribadian yang dibutuhkan. Dalam hal ini hukum dan kewajiban menjadi penentunya.

Menanggapi konflik peran dan kepribadian ini, Brouwer (1989) mengatakan bahwa manusia menyesuaikan diri dengan sadar dan dengan memikirkan kemungkinan - kemungkinan yang akan menghasilkan keadaan yang optimal. Orang yang mempunyai inteligensi yang tajam akan lebih berhasil dalam proses penyesuaian diri ini dibanding orang yang memiliki tingkat inteligensi rendah. Selain itu, orang yang mempunyai keseimbangan antara emosi dan rasio akan memperoleh kepribadian yang lebih sesuai dari pada orang bodoh yang emosional atau orang pintar yang dorongan - dorongannya terlalu lemah. Yang mustahil melakukan adaptasi adalah orang orang yang oligofren atau dement yang cenderung menarik diri dan sulit untuk dapat berinteraksi dangan hal - hal baru. Selain itu, orang - orang dengan tipe kepribadian neurose atau psychose yaitu mereka yang mengalami gangguan dalam kepribadian memiliki kemampuan adaptasi yang rendah.

Ketika kembali pada hukum dan kewajiban perempuan pada akhirnya harus menentukan di mana dia harus berdiri. Menentukan kepribadian yang selaras dengan nilai lingkungan sosial dan hasrat pribadinya. Dalam titik ini, tak jarang di antara mereka mengalami counter phobic façade yaitu suatu mekanisme pertahanan diri yang dilakukan dengan menyembunyikan ketakutan dan rasa tidak aman yang dialami yang merongrong kepercayaan diri. Sebuah kebingungan tentang siapa dan apa jati diri yang sebenarnya. Terperangkap di antara gagasan-gagasan sosial yang tua (konvensional) dengan gagasan gagasan yang baru dan radikal. Memenjarakan perempuan di dalam terali kebingungan akan kebebasan dan kemandirian dengan peran lama yang mengharuskan mereka jatuh dalam kenyataan diri tergantung pada orang lain secara finansial guna menjalankan perannya sebagai ibu rumah tangga (Dowling, 1989).

Kondisi ini kemudian dikenal istilah Cinderalla Complex yakni suatu jaringan sikap dan rasa takut yang sebagian besarnya tertekan sehingga wanita tidak bias dan tidak berani memanfaatkan sepenuhnya kemampuan otak dan kreativitasnya. Sebagaimana Cinderella yang terbaring di peti kaca menanti sang pangeran untuk membangkitkannya. Senantiasa menanti sesuatu yang berasal dari luar untuk mengubah hidup mereka. Dan menurut Dr. Horner seperti yang dikutip Dowling (1989) perempuan yang paling menderita ketakutan akan keberhasilan adalah mereka yang paling ingin berprestasi dan paling mampu berprestasi. Semakin besar kemampuan mereka, semakin cemas pula mereka. Tak jarang mereka berfikir bahwa keberhasilan secara professional akan membahayakan hubungan mereka dengan pasangannya dan keluarganya. Terlebih menurut Jessie Bernard dalam (Dowling, 1989) dalam bukunya yang berjudul The Future of Marriage ditemukan bahwa para pria professional masa kini ternyata masih mencari ibu bagi keturnan mereka. Mereka tidak mencari perempuan profesional yang dapat berfungsi di dunia dengan kecanggihan dan kemandirian yang sama dengan mereka, kaum pria. 
Strategi Coping Terhadap Ancaman Identitas: Memahami Kembali Pembeda Antara Perbedaan Jenis Kelamin dan Perbedaan Gender dalam Pekerjaan

Uraian di atas tampak gamblang menjelaskan polemik yang muncul di dalam diri seorang perempuan. Lalu bagaimana seharusnya perempuan menghadapi kondisi ini? Dalam dunia psikologi hal ini dikenal dengan istilah coping strategy yaitu suatu pikiran atau tindakan yang berguna untuk mengurangi atau memperbaiki efek ancaman baik yang secara nyata dapat disadari sebagai sebuah bentuk upaya yang disengaja atau pun tidak disenggaja. Terdapat tiga target tindakan coping yang dilakukan oleh seseorang menurut (Brakwell, 1986):

1. Memindahkan berbagai aspek dari konteks sosial baik dalam level material maupun ideologis yang dapat memunculkan ancaman

2. Bergerak menuju posisi sosial yang baru yang memiliki tingkat ancaman yang lebih kecil/sedikit

3. Merevisi kembali struktur identitas termasuk menyangkut dimensi isi atau nilai yang memungkinkan proses identitas dapat bekerja kembali berdasar pada prinsip keberlanjutan, keberbedaan dan berbasis pada harga diri (self esteem)

Ketiga strategi tersebut dapat dilakukan dalam tiga tingatan /level yang berbeda yaitu pada level intra - psychic, interpersonal dan intergroup. Ketiga level ini memiliki efek domino dan biasanya terjadi berawal dari level antar kelompok selanjutnya ke antar individu dan akirnya pada individu.

Berdasarkan penjalasan tersebut tampak bahwa upaya coping terhadap ancaman identitas bagi perempuan di dalam pekerjaan harus berawal dari level antar kelompok. Dengan artinya kebijakan dan aturan menjadi sangat penting dalam menentukan divisi pekerjaan, the sexual division of labour. Breakwell (1986) kembali menjelaskan bahwa tiga orentasi divisi kerja berbasis jenis kelamin (sex) sebagai sebuah bentuk upaya dalam kontek interaksi antar kelompok yang dapat dilakukan,

1. pembagian porsi kerja yang didasarkan pada perbedaan psikologis dan kapasitas biologis masing masing jenis kelamin.

Pendekatan ini mengindikasikan bahwa wanita memiliki peluang dalam pekerjaan yang lebih membutuhkan ketelitian, ketekunan dan sedikit tuntutan dalam kapasita kekuatan tenaga. Walapun pada akhirnya pendekatan ini harus menghadapi kenyataan bahwa tidak sedikit laki - laki yang memiliki kemampuan bekerja dengan tingkat ketekunan dan ketelitian yang tinggi dan tidak sedikit juga perempuan yang mampu melakukan pekerjaan yang membutuhkan kapasitas tenaga yang besar

2. pembagian porsi kerja yang lebih memfokuskan pada proses sosialisasi

Pendekatan ini menekankan pada bagaiamana proses sosialisasi tentang pekerjaan yang dilakukan laki-laki dan perempuan. Konsep tentang sex differences dan gender differences menjadi mengemuka. Yang pertama menekankan pada perbedaan jenis kelamin secara biologis sedangkan yang kedua menekankan pada proses pembelajaran yang mengindikasikan bahwa maskulinitas atau feminitisa tidak terkait lengsung dengan identitas sexual secara biologis.

3. pembagian porsi kerja yang didasarkan proses ekonomi.

Pendekatan ini mengindikasikan adanya peran ganda yang dijalani oleh perempuan. Pekerjaan bagi perempuan hanyalah sebagai pelengkap. Oleh sebab itu, seorang perempuan yang bekerja tidak dapat lepas 


\section{3-115 | HARKAT: Media Komunikasi Islam Tentang Gender dan Anak, 11(2), 2015}

dari keterikatannnya terhadap tanggung jawab yang lain yaitu suami dan keluarga. Atas landasan ini pula kemudian pekerja perempuan dibayar lebih rendah dibanding pekerja laki - laki. Dalam perspektif ini pula, pekerja perempuan dipandang tidak terlalu signifikan dalam memberikan imbas ekonomi karena tidak sebebas laki - laki dalam melaukan pekerjaan mereka.

Analisis dalam konteks hubungan antar kelompok ini memiliki imbas yang sangat besar pada pengambilan coping strategy pada level antar individu dan level di dalam diri individu. Sebagai contoh, adalah sulit bagi si ibu dengan persoalan psikologis yang dialami oleh anaknya disekolah untuk bergerak sendiri menyuarakan persoalan pribadinya tanpa ada landasan hukum yang jelas ketika kondisi ini dihadapkan pada hukum dan kewajiban yang dia emban sebagai pekerja.

\section{Aktualisasi Diri dan Kemulyaan Perempuan}

Dalam bukunya Mursi (1997) menjelaskan bahwa pekerjaan merupakan hak, kewajiban dan kehidupan. Diantaranya adalah hak bagi penduduk untuk memperoleh pekerjaan yang sesuai dengan potensi,kemampuan, pengetahuan dan pengalamannya. Ia harus mengeluarkan kemampuannya secara optimal dalam bekerja sehingga mampu merealisasikan kelayakan produktifitas. Seperti firman Allah, "Maka surga itulah sebaik - baik balasan bagi orang - orang yang beramal". (QS az-Zumar : 74).

\section{Selanjutnya Mursi (1997) mengutip} pendapat Karel Rogerz yang menjelaskan ciri ciri umum kepribadian seimbang yang disarikan dari riset yang dilakukannya terhadap para pekerja yang mampu bekerja secara produktif, yaitu:

1. Bersikap terbuka, menerima berbagai pengalaman, dan berusaha memahami perasaan - perasaan internalnya
2. Hidup secara eksistensialistik, yakni memiliki kepuasan batin bahwa tiap saat ia menginginkan pengalaman baru. Ini berarti bahwa memiliki perasaan internal bahwa ia bergerak dan tumbuh

3. Dalam struktur keanggotaannya, ia menemukan hal yang dipercaya untuk mencapai tingkah laku yang paling banyak memberikan kepuasan dalam tiap kondisi nyata. Ia melakukan apa yang dirasakan benar dalam konteks kekinian. Ia berpegang pada pembentukan totalitas dan komprehensif pada dirinya untuk mengarahkan tingkah laku sesuai pengalaman.

Pertanyaan yang asasi bagi uraian tersebut di atas adalah, "Apakah produktifitas yang dimaksud juga berlaku bagi perempuan dalam segala bidang pekerjaan yang diembannya?”.

Al-Ghazali, (1990) memberikan ulasan yang sangat indah dalam bukunya. Dengan mengutip firman Allah dalam Surat Al - Tahrim, "Wahai orang - orang yang beriman, peliharalah dirimu dan keluargamu dari api neraka yang bahan bakarnya adalah manusia dan batu”, dia ingin menjelaskan pentingnya keluarga bagi kehidupan manusia. Penulis berpendapat bahwa perspektif ini sangat penting guna menjawab persoalan multi peran yang dialami oleh perempuan. Artinya, peran lama yang dipandang tua dalam pendangan Dowling (1989) ternyata memiliki implikasi yang sangat besar bagi kebaikan individu dan bangsa ke depan. Bukan berarti pula menafikan persoalan psikologis yang dialami oleh perempuan dengan tuntutan hukum dan kewajiban yang diembannya sebagai pekerja dan sebagai ibu rumah tangga. Negosiasi di antara keduanya tampaknya sangat penting untuk dilakukan.

Rumah tangga menurut Al-Ghazali (1990) mempunyai pengaruh yang besar terhadap pertumbuhan anak - anak, dan menentukan masa depan mereka bahkan jaluar pertama 
pewarisan agama dan bahasa. Para ulama dalam bidang akhlak menegaskan bahwa dua unsur yang sangat menentukan dalam pendidikan dan tingkah laku adalah hereditas dan lingkungan, kendati mereka berbeda pendapat tentang mana di antara keduanya yang lebih kuat pengaruhnya. Peran rumah tangga dalam mendidik anak anak laki - laki dan perempuan harus didasarkan pada politik akademis dan moralitas baru. Jika tidak demikian, kita akan menuju pada kehancuran. Pemuda yang kuat dan cerdas adalah buah dari masa kanak - kanak yang selamat dari pengabaian dan keteledoran, dibimbing oleh ibu yang cerdas dan ayah yang energik. Oleh karena itu, tugas ibu rumah tangga bukan tugas yang mudah. Ia merupakan jembatan lain di luar pemberian kesenang dan penyaluran hasrat seksual, "Ibu adalah sekolah, jika engkau mempersiapkannya, berarti engkau mempersiapkan pemuda yang berketurunan baik".

Hal ini mengindikasikan bahwa, seorang ibu harus kuat dan cerdas. Setidaknya ada dua hal yang harus ditingkatkan nilai profesionalitasnya dari seorang perempuan dalam perannya sebagai ibu. Pertama, dia tidak boleh bodoh dan harus mengerti banyak hal terutama tentang dirinya sendiri dan tentang dunia. Kedua, dia tidak boleh bergantung pada pada urusan - urusan yang remeh, macam - macam perhiasan, dan bentuk peradaban modern yang menjauhkan mereka dari kecerdasan, kesenangan dan keunggulan individu serta sosial.

Untuk menegakan peran yang mulya tersebut Al-Ghazali (1990) menegaskan bahwa adalah suatu hal yang penting bagi kaum wanita untuk memiliki peran intelektual dan politik. Terlibat dalam program - program masjid dan organisasi sosial serta medan perjuangan. Sehingga pemikiran yang mengatakan bahwa menyebut namanya aib, melihat wajahnya adalah haram, dan suaranya adalah aurat di mana tugasnya hanya merapikan tempat tidur harus diganti dengan konsep perempuan yang cerdas, kuat dan memegang prinisp agama penuh kemulyaan.

Berdasarkan uraian tersebut nyata. Konflik peran yang diemban oleh perempuan bukanlah hal yang mudah untuk hadapi. Perbadaan kemampuan setiap individu dalam menghadapi persoalan memang tak selalu sama. Namun demikian, tuntunan dari Allah dalam firman Nya yang berbunyi, "Allah tidak memikulkan beban kepada seseorang melainkan (sekedar) apa yang Allah berikan kepadanya..." (QS, ath - Thalaq $65: 7)$.

Adalah hal yang sangat penting bagi para perempuan untuk terus menyuarakan segala hal yang menjadi haknya dan terus berkembang untuk dapat berkontribusi dalam segala bidang kehidupan terutama terkait misi utama mereka adalah menjalankan perannya secara profesional dan proporsional sebagai ibu di rumah dan sebagai pekerja.

\section{PENUTUP}

Dalam bukunya Hickman, (1990) menjelaskan bahwa pada prinsipnya dalam diri manusia terdapat dua peran yang sangat esensial, yaitu sebagai manager dan peran sebagai pemimpin. Dalam konteks peran sebagai menager, individu dituntut untuk mampu memahami detil pekerjaan dan pencapaian yang hendak diwujudkan. Namun disisi lain, dalam posisinya sebagai pemimpin individu harus mampu membawa dirinya pada pencapaian yang diinginkan. Artinya, sebuah target yang ditetapkan inidvidu hanya dapat direalisasikan oleh seorang pemimpin yang mampu mewujudkannya dengan karakter yang disesuaikan dengan kebutuhan pencapaian.

Salah satunya adalah prinsip tentang manager like formality, leader like informality. Kedua peran ini akan memudahkan perempuan dalam mengambil sikap terbaik dalam setiap 


\section{5-115 | HARKAT: Media Komunikasi Islam Tentang Gender dan Anak, 11(2), 2015}

keputusan hidupnya. Ketika bertugas sebagai ibu rumah tangga di rumah maka dia bersikap sebagai manager rumah tangga, memahami semua tugas yang harus dilakukan dengan pendekatan layaknya sebagai seorang pemimpin yang berusaha untuk membuat nyaman anggotanya dengan bersikap tidak terlalu formal tapi bersahabat. Sebaliknya, ketika berada di dalam dunia pekerjaan maka dia menjadi manager dengan pekerjaannya dan bersikap layaknya pemimpin dalam berinteraksi dengan hal - hal lain di luar pekerjaannya yaitu bersikap lebih informal, santai dan tidak terbeban satu tugas yang berat.

Dengan demikian, pada dasarnya peran perempuan sangatlah strategis. Kunci penting bagi keberhasilan lahirnya generasi penerus bangsa. Konflik peran yang diemban perempuan jangan lah dijadikan penghambat. Justru harus diperjuangkan. Diantaranya adalah mendorong lembaga di mana perempuan bekerja untuk dapat memfasilitasi para pekerja perempuan dengan kegiatan yang mencerdaskan dan fasilitas yang memudahkan perempuan melakukan pekerjaannya tanpa harus meninggalkan perannya sebagai ibu bagi anak - anaknya. Wallahu a'lam.

\section{DAFTAR PUSTAKA}

Al-Ghazali, S. M. (1990). Mulai Dari Rumah: Wanita Muslimah dalam Pergumulan Tradisi dan Modernisasi. Jakarta: Mizan.

Bouchet, J., Chanton, O., Kreel, V., Maze, C., Ric, F., \& Richard, G. (1992). Psychologie Sociale (Vol. Tome 2). Paris: Breal.

Brakwell, G. (1986). Coping With Threatened Identities. New York: Methuen.

Brouwer, M. (1989). Perubahan Kepribadian. In M. Brower, Kepribadian dan Perubahannya (p. 4). Jakarta: Gramedia.

Dowling, C. (1989). Cinderella Complex: Ketakutan Wanita Akan Kemandirian. Jakarta: Erlangga.

Hickman, C. R. (1990). Mind of A Manager, Soul of a Leader. New York: John Wiley \& Sons.

Hogg, M. A., \& Vaughan, G. (2010). Essentials of Social Psychology. Harlow: Prentice Hall.

Mischel, W., Yuichi, S., \& Ayduk, O. (2007). Introduction To Personality: Toward an Integrative Science of The Person (8th ed.). Danvers: John Wiley \& Sons. Inc.

Mursi, A. H. (1997). SDM Yang Produktif: Pendekatan Al-Quran dan Sains. Jakarta: Gema Insani Press. 